\title{
PHYSALIS MACROSPERMA (SOLANACEAE: PHYSALINAE), A NEW PSAMMOPHYTE ENDEMIC TO THE WEST GULF COASTAL PLAIN OF THE SOUTHEASTERN U.S.A., A GLOBAL BIODIVERSITY HOTSPOT

\author{
Avon Park Air Force Range \\ 29 South Blvd. \\ Avon Park AFR, Florida 33825, U.S.A.
} \\ Steve L. Orzell
}

\author{
Milo Pyne \\ NatureServe / UNC-CH Herbarium (NCU) \\ University of North Carolina at Chapel Hill \\ Campus Box 3280 \\ Chapel Hill, North Carolina 27599-3280, U.S.A. \\ milopyne@yahoo.com \\ Edwin L. Bridges \\ 5904 72nd Ave., NW \\ Gig Harbor, Washington, 98335-6667, U.S.A.
}

Derick Poindexter

\author{
UNC-CH Herbarium (NCU) \\ University of North Carolina at Chapel Hill \\ Campus Box 3280 \\ Chapel Hill, North Carolina 27599-3280, U.S.A.
}

\section{ABSTRACT}

\begin{abstract}
A new species of Physalinae (Solanaceae) is described and illustrated that is endemic to the West Gulf Coastal Plain of the southeastern United States, a global biodiversity hotspot. Physalis macrosperma sp. nov. is distinguished by its large obpyramidal fruiting calyx (35-70 mm in length), its large seeds [3.2-4.2(4.8) mm in length and 2.5-3.5(3.9) $\mathrm{mm}$ in width], and its coarsely pitted seed testa. The ecological and geographical setting of P. macrosperma and its morphological relationships with similar taxa are presented. Physalis macrosperma is an herbaceous perennial psammophyte inhabiting open sand barrens within pyrogenic savanna-woodlands of xeric sandhills. It occurs on droughty undulating Eocene-age quartzipsamments within south-central and east-central Texas and on younger xeric sands embedded within the fire-maintained pinelands of southwestern Arkansas, western Louisiana, and southeastern Texas.
\end{abstract}

\section{RESUMEN}

Se describe e ilustra una nueva especie de Physalinae (Solanaceae) que es endémica de la llanura costera del oeste del Golfo, en el sudeste de los Estados Unidos, un punto de gran biodiversidad a nivel mundial. Physalis macrosperma sp. nov. se distingue por su gran cáliz fructífero obpiramidal (35-70 mm de longitud), el diámetro de las semillas [3.2-4.2(4.8) mm de longitud y 2.5-3.5(3.9) mm de ancho], y la testa de la semilla que es característicamente groseramente foveolada. Se presenta el entorno ecológico y la distribución geográfica de P. macrosperma y sus relaciones morfológicas con taxones similares. Physalis macrosperma es una hierba psanmófila perenne que habita en arenales abiertos en bosques de sabana pirógena de arenales y dunas xéricas. Ocurre en suelos cuarcíticos ondulados y secos del Eoceno en el centrosur y centro-este de Texas y en arenas xéricas más jóvenes incrustadas en el pinar mantenido por fuego en el sudoeste de Akansas, el oeste de Luisiana y el sudeste de Texas.

Key Words: Physalis, Solanaceae, West Gulf Coastal Plain, psammophyte, endemic, Physalinae

Physalis L. (Solanaceae, subtribe Physalinae sensu Hunziker 2001) is a diverse, primarily New World genus with 75-90 species, often referred to as ground-cherries or husk-tomatoes. It is readily recognized by its inflated lantern-shaped fruiting calyx (the "husk" or "bladder") which envelops a fleshy berry. The fleshy berry is of exceptional economic and cultural significance (Wilf et al. 2017). The genus, although well studied, has a convoluted taxonomic history (Rydberg 1896; Sullivan 2013; Waterfall 1958, 1967) with obscure evolutionary origins. Martinez (1999) recognized four subgenera and 12 sections within Physalis. Recent molecular evidence by Zamora-Tavares et al. (2016) has shown these sections to be paraphyletic.

The area of origin for the subtribe Physalinae is the New World, except for the former type of the genus Physalis alkekengi L. now Alkekengi officinarum Moench (Applequist 2012; Wang 2014). Based upon fossil evidence, Physalis is now strongly supported to have diverged prior to the breakup of the Gondwanan supercontinent some 52 million ybp, rendering the inflated calyx syndrome as an ancient lineage (Wilf et al. 2017). Previously, molecular data had attributed its divergence to the end of the Miocene (Zamora-Tavares et al. 2016). Within the subgenus Rydbergis Hendrych of Physalis, to which we ascribe Physalis macrosperma, there are 60+ 
New World, mostly Mexican, species. Subgenus Rydbergis is thought to have undergone rapid diversification during the Pliocene and Pleistocene epochs (Vargas et al. 2001; Whitson \& Manos 2005; Zamora-Tavares et al. 2016).

In the southeastern United States (sensu Cronquist 1980; exclusive of Texas), Sullivan (2004) recognized 16 native species of Physalis. With generic realignments since 2004, this number has since been reduced to 14 species (Sullivan in press). Some members of the genus have medicinal or ornamental value while others are cultivated for their edible fruits (Whitson \& Manos 2005). The economic value of Physalis fruits has resulted in wide human-dispersal into warm areas world-wide (Whitson \& Manos 2005). This has confounded assessment of the original geographic distribution and habitat preferences of some species, with many thriving in human-altered habitats.

During taxonomic studies of Physalis from the southeastern United States and examination of specimens at Vanderbilt Herbarium (now BRIT-VDB), the senior author uncovered several specimens with exceptionally large calyces. Collections of similar material made by co-authors Orzell and Bridges from southwestern Arkansas in 1985 and from east-central Texas counties in 1988 and 1989, led us to collaborate our efforts to study this Physalis. The study objectives were: 1) to describe this novel entity in relation to other closely allied taxa (i.e., taxa with highly accrescent calyces) using herbarium and morphometric studies, 2) to determine its geographic distribution, 3) to describe its ecological preferences, and 4) to provide an updated taxonomic key to it and similar sympatric species.

\section{MATERIALS \& MORPHOMETRIC METHODS}

\section{Literature/Herbaria Survey}

Review of existing taxonomic and phylogenetic treatments of Physalis was supplemented with herbarium surveys aimed at determining taxa morphologically allied to our potential new entity (P. macrosperma). The senior author examined over 900 sheets of Physalis from 20 herbaria (BRIT, BRIT-VDB, CM, DUKE, GH, LAF, LSU, MO, NCSC, NCU, NLU, NY, SIU, SMU, TEX, TEX-LL, UC, US, USCH, and USF). We suspected that the rather large inflated calyces of our entity might be of taxonomic significance. Both literature and examination of herbarium specimens helped identify other species bearing highly accrescent fruiting calyces. However, in some herbarium specimens this character can be difficult to discern (Sullivan 2004), since drying and pressing can easily distort the shape of the inflated calyx and its enveloped berry (Whitson \& Manos 2005). Our examination of voucher specimens uncovered numerous sheets of our potential new entity along with annotations or determinations which refined identification of other species of Physalis with similar morphological traits (Appendix 1). The senior author also examined the lectotype and isolectotype of Physalis macrophysa Rydb. to determine if our entity might fall within the taxonomic concept of P. macrophysa.

\section{Morphometric Analysis}

Our dataset included 59 specimens. Flowering and fruiting specimens were separately assessed, using different suites of 13 characters for each group (Table 1). The characters of relative abundance for the six different hair types and leaf base shape were common to both datasets. The other six characters were different for flowering and fruiting specimens. For measuring continuous characters, we adopted a coding system to examine discrete variables (Table 1). In the analysis of the fruiting specimen dataset, only 12 of the 13 characters were used; calyx width was not used because of its high correlation with calyx length. We used PCoA (Principal Coordinates Analysis) to analyze our morphometric datasets (both discrete and continuous variables) in order to assess similarity and species delineation among specimens within ordination space. Principal coordinates analysis was performed using XLSTAT 2013 software (XLSTAT, New York, NY, USA). Principal components and nonparametric analyses were conducted using JMP® version 11 software (SAS Institute, Cary, NC) on an Apple $\circledR^{\text {MacBook Pro }}{ }^{\mathrm{TM}}$ computer.

\section{RESULTS \& DISCUSSION}

Literature, herbaria, and morphometric studies lead us to conclude that Physalis macrosperma within subgenus Rydbergis Hendrych (Whitson \& Manos 2005) is a distinct taxon. Subgenus Rydbergis typically includes 
TABLE 1. Characters measured on flowering and fruiting specimens of Physalis macrosperma used in PCoA analysis; see below for explanation of character codes.

FLOWERING SPECIMEN CHARACTER

\section{Retrose hair}

Antrorse hair

Short-glandular hair

Pilose-spreading hair

Dendritic hair

Long-septate hair

Calyx+corolla length

Corolla exterior pilosity

Bud/calyx pubescence

Anther color

Leaf base shape

Corolla maculation type

Anther length
CODING TYPE

Abundance 0-3

Abundance 0-3

Abundance 0-3

Abundance 0-3

Abundance 0-3

Abundance 0-3

Measured (mm)

Abundance 0-3

Abundance/location 0-4

Categorized 0-3

Categorized 0-4

Categorized 0-4

Measured $(\mathrm{mm})$
FRUITING SPECIMEN CHARACTER

Retrose hair

Antrorse hair

Short-glandular hair

Pilose-spreading hair

Dendritic hair

Long-septate hair

Fruiting calyx length

Fruiting calyx width

Calyx length-width ratio

Calyx base depression

Leaf base shape

Seed length

Calyx shape (widest point)
CODING TYPE

Abundance 0-3

Abundance 0-3

Abundance 0-3

Abundance 0-3

Abundance 0-3

Abundance 0-3

Measured (mm)

Measured ( $\mathrm{mm})$

Calculated (mm)

Categorized 0-3

Categorized 0-4

Measured ( $\mathrm{mm}$ )

Categorized 0-4

Hair type abundance codes: $0=$ absent; 1 =sparse; $2=$ moderate; $3=$ dense

Bud/calyx pubescence abundance/location codes: $0=$ glabrous (hair absent); $1=$ hair on margin only; $2=$ hair on calyx angles; $3=$ hair on margins and angles; $4=$ hair widespread on bud/calyx

Anther color codes: $0=$ entirely yellow; $1=$ very minor blue areas; $2=$ significant blue areas; $3=$ entirely blue

Leaf base shape codes: $0=$ acuminate (angle $<45^{\circ}$ ); $1=$ cuneate (angle $45^{\circ}-90^{\circ}$ ); $2=$ rounded; $3=$ truncate; $4=$ cordate

Corolla maculation codes: $0=$ absent; 1 =vague; 2 = dendritic lines; $3=$ solid, pale; $4=$ solid, dark

herbaceous annuals or perennials possessing solitary unlobed yellow corollas with inflated fruiting calyces (Whitson \& Manos 2005; Zamora-Tavares et al. 2016). Recent phylogenetic studies (Zamora-Tavares et al. 2016) have established the monophylly of the Rydbergis clade.

Our herbarium studies showed that it is possible to confuse material of Physalis macrosperma with other perennial Physalis. Appendix 1 is a table of the specimens used in the morphometric analysis. It includes determinations and annotations of prior investigators to demonstrate the taxa with which P. macrosperma had been previously confused. We chose 59 sheets of five Physalis taxa (P. hederifolia A. Gray, P. heterophylla Nees, P. longifolia Nutt. var. subglabrata (Mackenzie \& Bush) Cronquist, P. virginiana Miller, and P. macrosperma) from the 900 herbarium sheets because these specimens bore either corollas and/or inflated calyces. The PCoA plots of the flowering (Fig. 1) and fruiting (Fig. 2) datasets show the relationships of the five taxa. There is a form of P. longifolia var. subglabrata (f. macrophysa [Rydb.] Steyermark), which also has larger than typical calyces (Pyne et al. 2019, this issue). In addition, large-calyced material of $P$. virginiana is sometimes encountered (Waterfall 1958). We also included some of this material. Our new entity is separated from these two species by characters other than calyx dimensions, including hair type. Physalis heterophylla was included because of its similarity in hair type to our new entity. Fruiting material of P. heterophylla and the new species is clearly separated due to differences in calyx dimensions. Several sheets of the new species were encountered which 


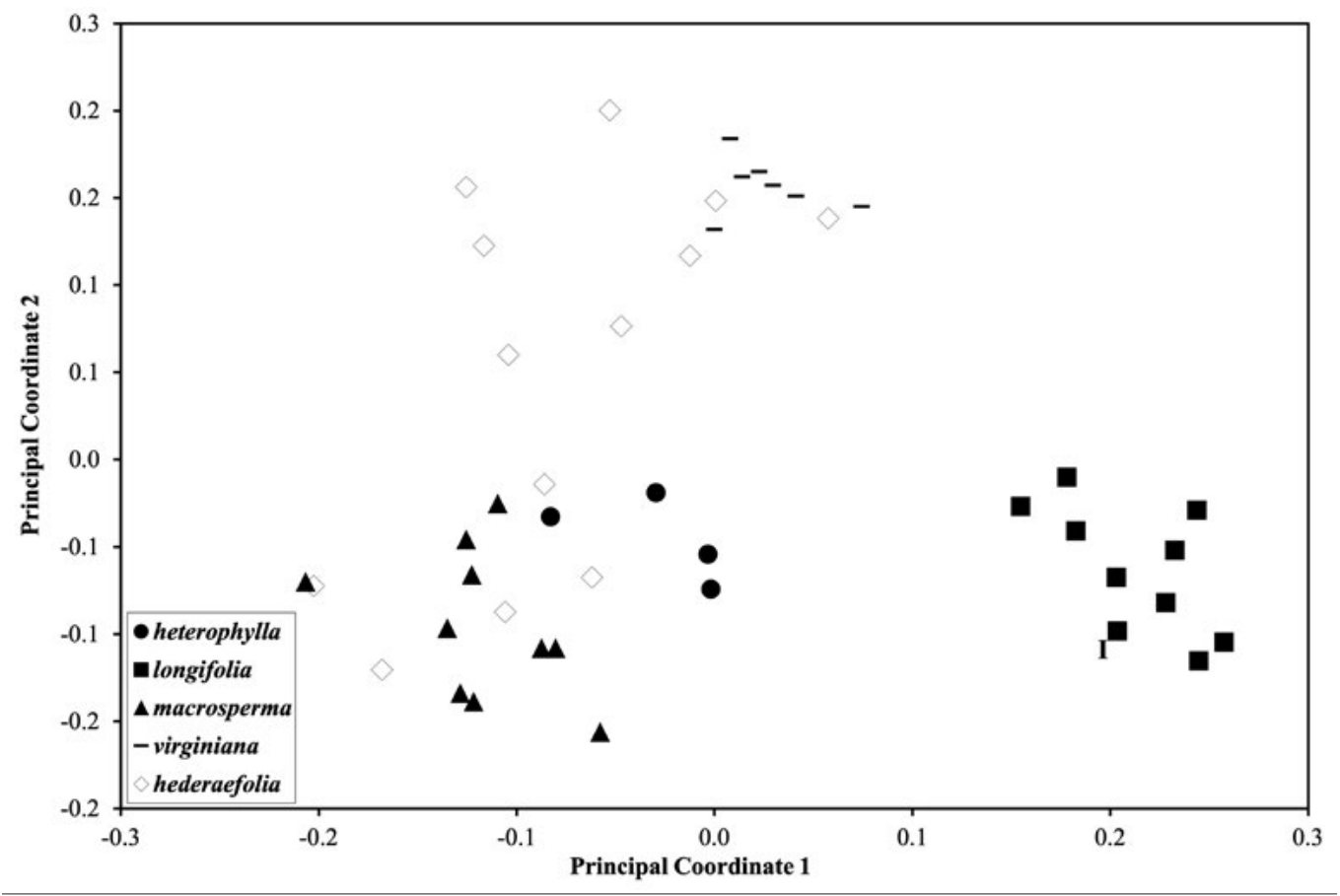

FIG. 1. Principal coordinates analysis of flowering specimens. The isolectotype (Heller 1756 [NY; barcode NY00138845]) of Physalis macrophysa denoted by "I;" "Iongifolia" includes both varieties, longifolia and subglabrata, of $P$. Iongifolia.

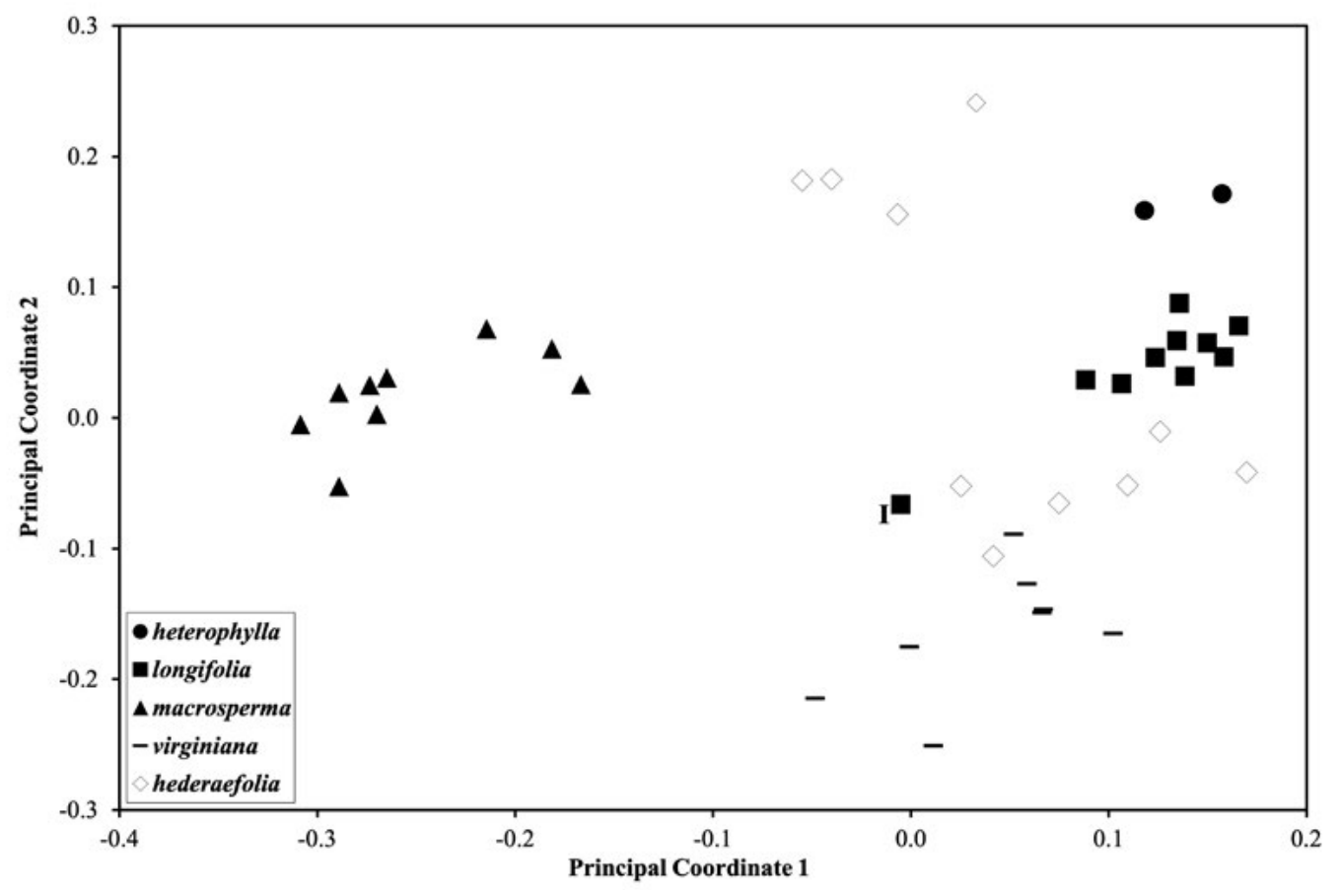

FiG. 2. Principal coordinates analysis of fruiting specimens. The isolectotype (Heller 1756 [NY; barcode NY00138845]) of Physalis macrophysa denoted by "I," "Iongifolia" includes both varieties, longifolia and subglabrata, of P. Iongifolia. 
had been determined as $P$. hederifolia (Pyne 2018), so material of it was included as well. Table 2 summarized the characters and their states that may be used to distinguish our new entity from other perennial Physalis taxa found within its range.

Our morphometric analysis of fruiting and flowering characters shows separation of the new entity $P$. macrosperma from all other sampled species. Concerning pubescence type, there is some intergradation of $P$. macrosperma, P. heterophylla, and P. hederifolia (Fig. 1). If we had opted to include the length of the spreading pubescence (generally less than $1 \mathrm{~mm}$ in P. macrosperma, greater than $1 \mathrm{~mm}$ in P. heterophylla) we suspect there may have been better resolution in the flowering dataset. The fruiting dataset, with calyx length included as a character, shows the distinctiveness of P. macrosperma (Fig. 2). In both datasets, $P$. hederifolia results reflect what we assume to be several varieties (Pyne 2018). Future taxonomic realignment of the P. hederifolia complex is warranted to better understand and evaluate recognition of varieties within the complex, but this effort is beyond the scope of our current research.

\section{TAXONOMIC TREATMENT}

Physalis macrosperma Pyne, E.L. Bridges, \& Orzell, sp. nov. Type: U.S.A. Arkansas. Miller Co.: open sandy field W of AR 237 and just E of Sand Hills State Natural Area, $4.1 \mathrm{mi}$ S of Sulphur River Bridge, W1/2 S17 T18S R28W, 8 Jun 2000, J. Gentry \& C. Reid 9238 (ноlotype: BRIT; IsotyPes: ANHC! (3; 011039, 011040, 011041; Barcode numbers ANHC011638, ANHC011639, ANHC011640), LSU, NY, NCU, UARK, US).

Similar to P. heterophylla Nees, but fruiting calyx longer, seeds of greater length and width with coarser seed testa pitting, hairs on stem shorter; similar to P. hederifolia A. Gray s.s., but fruiting calyx and pedicel longer, seeds of greater length and width with coarser seed testa pitting.

Figures 3, 4, and 5 compare the calyces, seeds, and stem pubescence of $P$. macrosperma and P. heterophylla; a similar comparison with $P$. hederifolia is not possible due to the great variety of material referred to this latter taxon. An image of the Holotype is provided as Fig. 6; illustrations of the plant and its flowers, fruit, etc. constitute Fig. 7; Figs. 8 and 9 are photographs of living or fresh material.

Perennial herb: becoming somewhat suffrutescent with age, the viscid stems and leaves often coated with fine sand, 150-600 mm tall, from a stout deeply buried rhizome, often with slender shallow rhizomes. Plants: semi-erect, to $600 \mathrm{~mm}$. Stems: pale green to brownish, erect to spreading, frequently widely spreading and sprawling across the ground; branching frequently; glandular-pubescent to villous and somewhat viscid with short, gland-tipped hairs, these mostly $0.2-0.5 \mathrm{~mm}$ long, some ranging up to $1.5(-2) \mathrm{mm}$ in length; also with longer, simple, eglandular, jointed, divergent hairs that are ca. $1 \mathrm{~mm}$ long. New growth densely pubescent. Leaves: alternate basally, geminate above, viscid leaf blades broadly ovate, triangular-ovate, to suborbicular; blades as small as $20-30 \mathrm{~mm}$ long and $10-20 \mathrm{~mm}$ wide in flowering material and up to $70 \mathrm{~mm}$ long and $40 \mathrm{~mm}$ wide when fruiting; glandular-pubescent to villous with a mixture of short glandular and nonglandular hairs; apex broadly acute; margins shallowly and irregularly toothed, sinuate to dentate to nearly entire; adaxial surface nearly glabrous and punctate to moderately pubescent with simple, gland-tipped and/or non-glandular trichomes; abaxial surface scarcely pubescent to pubescent with simple, gland-tipped and/or non-glandular trichomes; base truncate to rounded to subcordate, frequently with basal margins offset up to 7 $\mathrm{mm}$; petiole typically $50 \%$ to $60 \%$ of blade length, mostly $8-37 \mathrm{~mm}$ long. Pedicels: $4-15 \mathrm{~mm}$ long in flower, 13-26 mm in fruit, pubescent to densely pubescent; trichomes simple, gland-tipped and/or non-glandular. Flowers: solitary in leaf axils. Flowering calyx: 7-10(-12) mm long, villous, viscid, and often stipitate-glandular; lobes 2-4(-5) mm long, ovate to triangular, widely spreading and flanking a broad sinus which often forms an equilateral triangle (most evident when in live material); pedicel 6-15(-20) mm long, with a mix of short, gland-tipped and longer, simple, jointed, divergent hairs. Fruiting calyx: green (becoming yellowish-green or stramineous when dried), 10-ribbed, slightly 5-angled to rotate in cross-section, recessed 5-8(-10) $\mathrm{mm}$ at base; lobes 3.7-7.1 mm long, apices acute; entire calyx (35-)50-70 mm long, 25-44 mm broad, obpyramidal, broadly triangular, widest at basal (proximal) end, tapering from a wide base to a narrow and acute tip. Corolla: rotate-campanulate, slightly pentagonal, light yellow, typically with 5 large evident purple-brown basal maculations in throat; $12-17 \mathrm{~mm}$ long, mostly glabrous with minutely pubescent bands along the main 


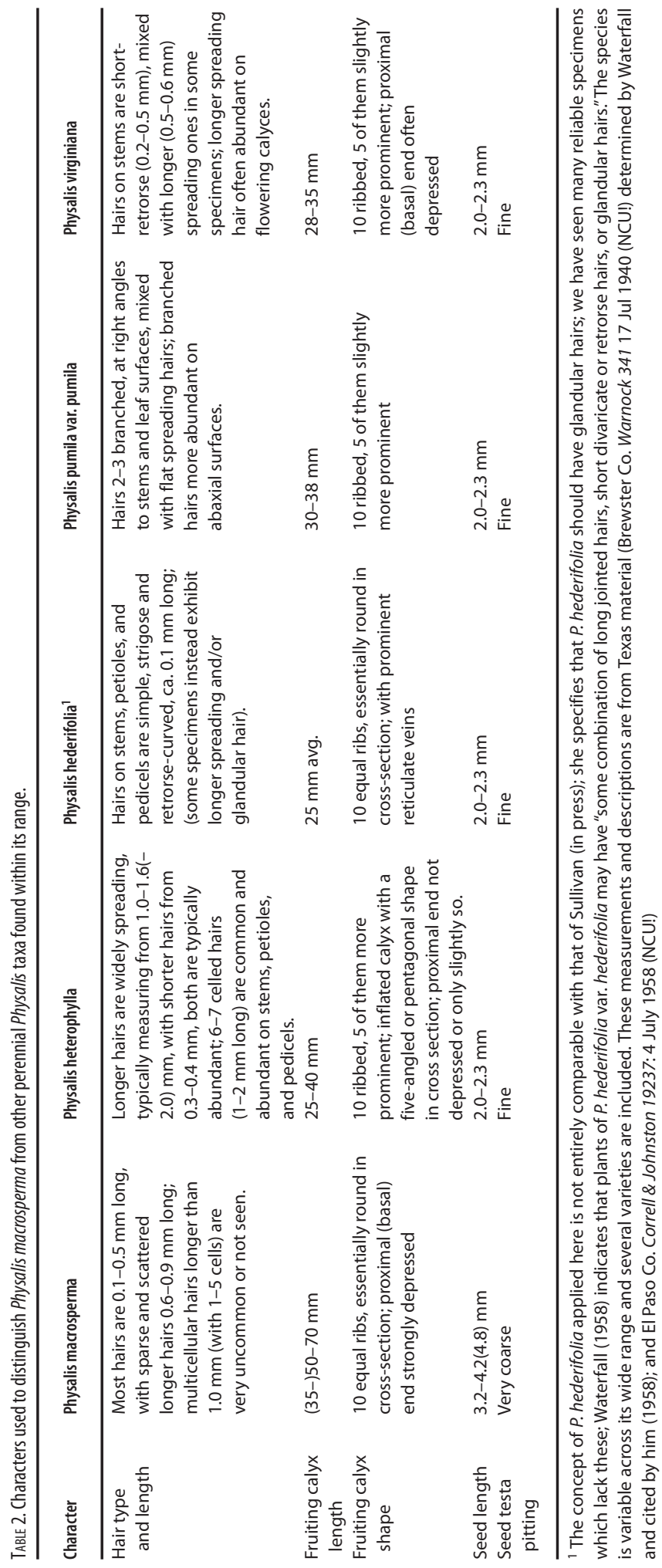

This document is intended for digital-device reading only. 


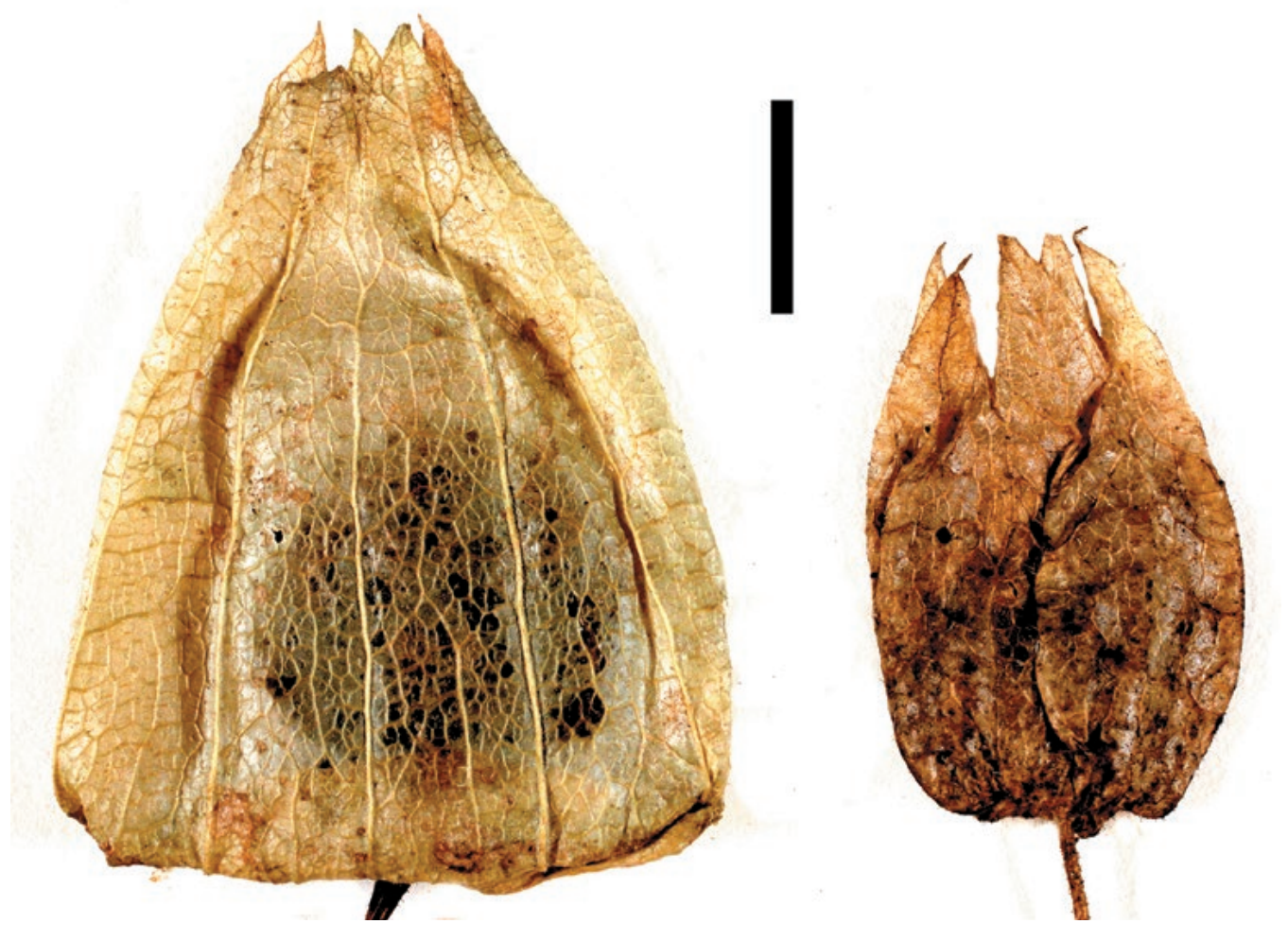

FIG. 3. Fruiting calyces of $P$. macrosperma (left) and $P$. heterophylla (right). Bar $=10 \mathrm{~mm}$.

nerves and margins without, glabrous except for a densely tomentose band near the point of anther insertion within; trichomes simple; apices narrowly acute to short-acuminate. Stamens: 4.1-6.1 mm long; anthers varying in color from yellow, lightly tinged blue, or darker brown, 2.2-2.6 mm long. Pistils: 7.4-9.9 mm long; ovary glabrous; style glabrous, 5.3-7.5 mm long; stigma greenish-brown, only slightly broader than the style. Berry: green becoming reddish-brown, globose, $13-23 \mathrm{~mm}$ in diameter, somewhat viscid when fresh, suspended in the basal half of the inflated calyx. Seeds orange-brownish, nearly round in outline and flattened, 3.2-4.2(-4.8) $\mathrm{mm}$ long and 2.5-3.5(-3.9) mm wide when mature, testa with distinct coarse pitting, with fewer than 10 regular depressions per millimeter. Phenology: Flowering March to late April through September. $(n=12)$.

\section{KEY TO SELECTED PERENNIAL PHYSALIS OF SOUTH-CENTRAL UNITED STATES}

The key below, based in part to the key in Sullivan (in press) and Cascio (1994), is to perennial pubescentleaved, rhizomatous Physalis species of the south-central United States, with 10-ribbed fruiting calyces, including Physalis heterophylla, P. pumila var. pumila, and P. hederifolia. The proposed new entity does not overlap in range with P. pumila var. hispida, but this taxon is included for completeness.

1. Plants pubescent with 2-3-branched hairs

Physalis pumila var. pumila

1. Plants densely pubescent with primarily simple hairs (appressed, strigose, or divergent, glandular or nonglandular, or rarely glabrous).

2. Leaf blades broadly ovate to suborbiculate; plants often glandular.

3. Pedicels $4-8(-13) \mathrm{mm}$ in flower, $5-15 \mathrm{~mm}$ in fruit

Physalis hederifolia

(sens. str.; not including P. fendleri [P. hederifolia var. cordifolia])

3. Pedicels (8-)9-17(-45) in flower, 15-30(-35) in fruit; plants densely villous, hairs divergent.

4. Hair mostly $1 \mathrm{~mm}$ long or longer, some up to $2 \mathrm{~mm}$ in length; mature fruiting calyx $20-40 \mathrm{~mm}$ long, seeds $2.0-2.3$

$\mathrm{mm}$ in length, $1.7-2.0 \mathrm{~mm}$ in width; upper leaf surfaces glandular-pubescent to densely viscid-pubescent; leaves 
ovate to broadly ovate; widespread in eastern and central United States and adjacent southern Canada

Physalis heterophylla

4. Hair mostly $0.2-0.5 \mathrm{~mm}$ long, a few up to $1.5(-2.0) \mathrm{mm}$ in length; mature fruiting calyx (35-)50-70 $\mathrm{mm}$ long, seeds $3.2-4.2(-4.8) \mathrm{mm}$ in length and $2.5-3.5(-3.9) \mathrm{mm}$ in width; upper leaf surfaces punctate to sparsely glandular-pubescent; leaves triangular-ovate to deltoid; restricted to sands of central Texas. sw Arkansas and w Louisiana

Physalis macrosperma

2. Leaf blades narrowly ovate to elliptic, broadly lanceolate, or oblanceolate; plants not glandular and with simple hairs only.

5. Plants glabrous or sparsely strigose with antrorse hairs to $0.5 \mathrm{~mm}$

Physalis longifolia

5. Plants moderately to densely pubescent with divergent hairs $1-1.5 \mathrm{~mm}$, antrorse or retrorse hairs to $0.5 \mathrm{~mm}$.

6. Plants erect; leaf margins coarsely to shallowly dentate or entire; hairs divergent and retrorse

6. Plants decumbent; leaf blades elliptic-ovate; leaf margins entire or undulate; hairs divergent and antrorse;

flowering calyces and pedicels hispid; plants of Great Plains

Physalis pumila var. hispida

Distribution, Habitat, and Ecology.-Physalis macrosperma has been vouchered from 23 counties and 6 parishes, with the majority of specimens (Appendix 2) from Texas (Fig. 10). It ranges from south-central Texas (Bexar and Wilson counties) east and north along the Sabine Uplift to southwestern Arkansas (Miller County), and into western and north-central Louisiana (Beauregard, Caddo, Sabine, Union, Vernon, and Winn parishes). All occurrences are from xeric sands within the West Gulf Coastal Plain (WGCP) of Texas, Louisiana, and Arkansas, including the Post Oak Savannah and Pineywoods ecoregions of Gould $(1962,1969)$ cited in

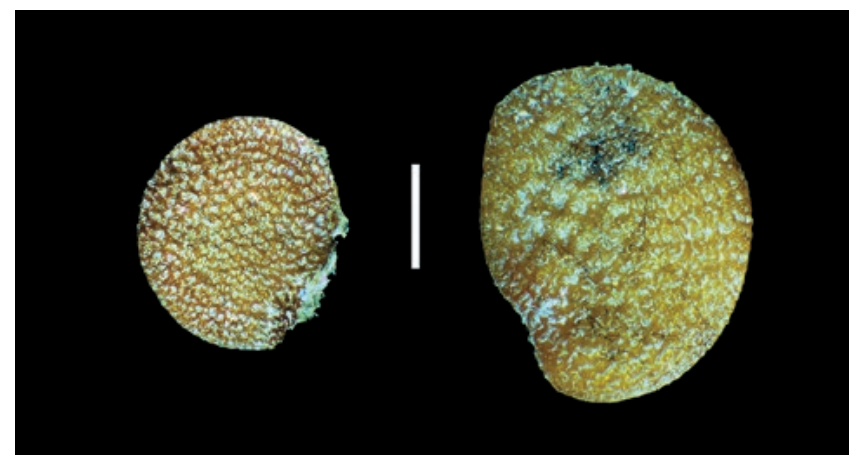

Fig. 4. Mature seeds of $P$. macrosperma (left) and $P$. heterophylla (right). Bar $=1 \mathrm{~mm}$.
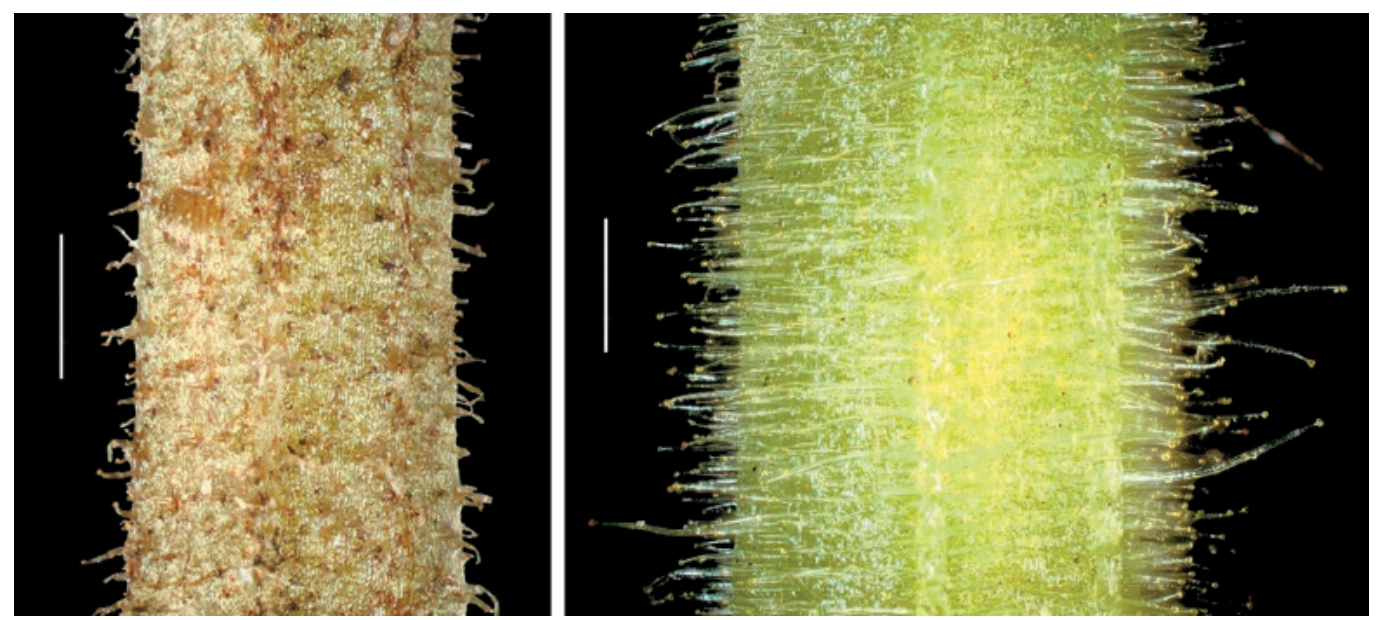

Fig. 5. Stem pubescence of $P$. macrosperma (left) and $P$. heterophylla (right). Bar $=1 \mathrm{~mm}$. 


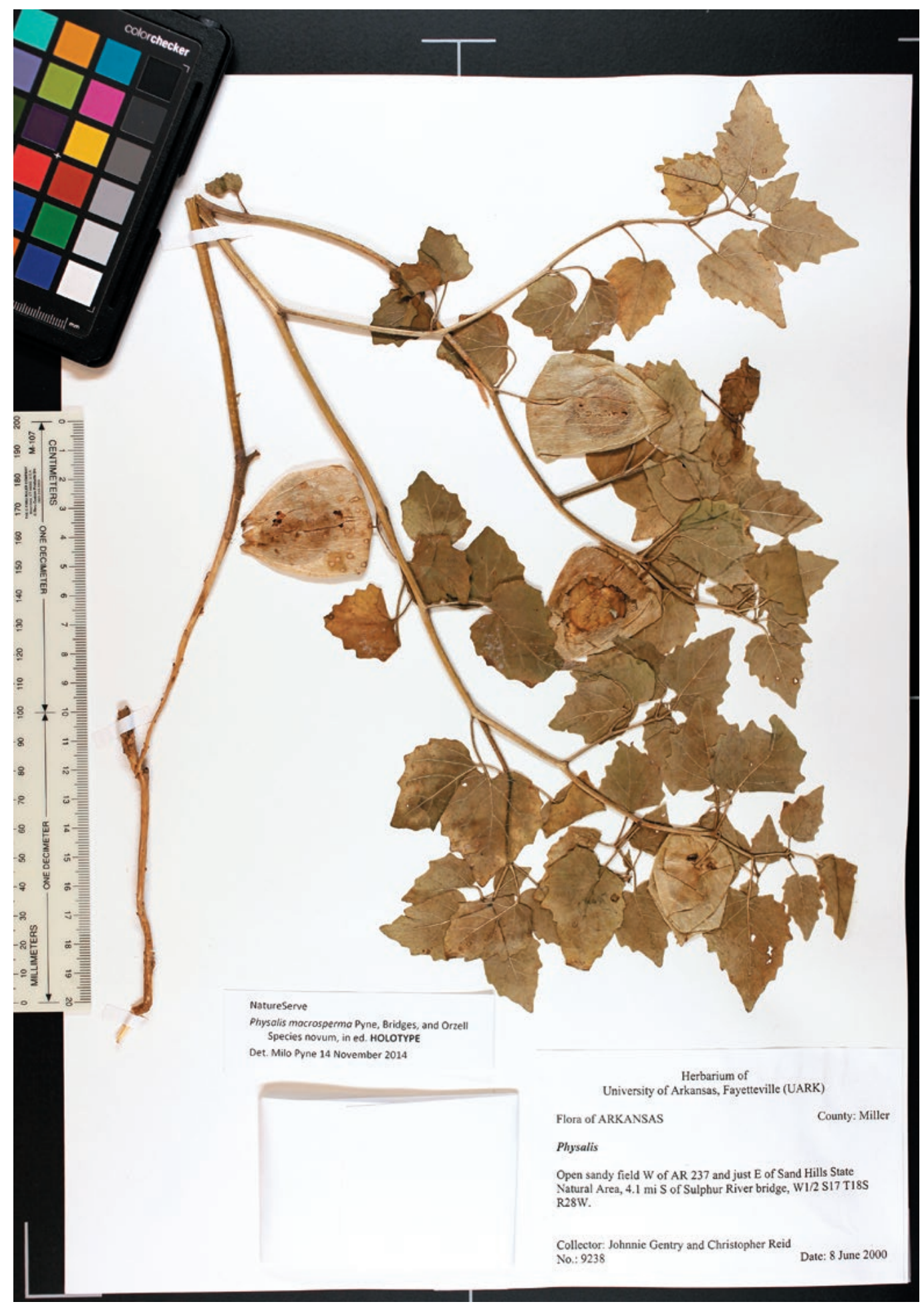

FIG. 6. Holotype of Physalis macrosperma Pyne, Bridges, and Orzell (J. Gentry \& C. Reid 9238) (UARK). 


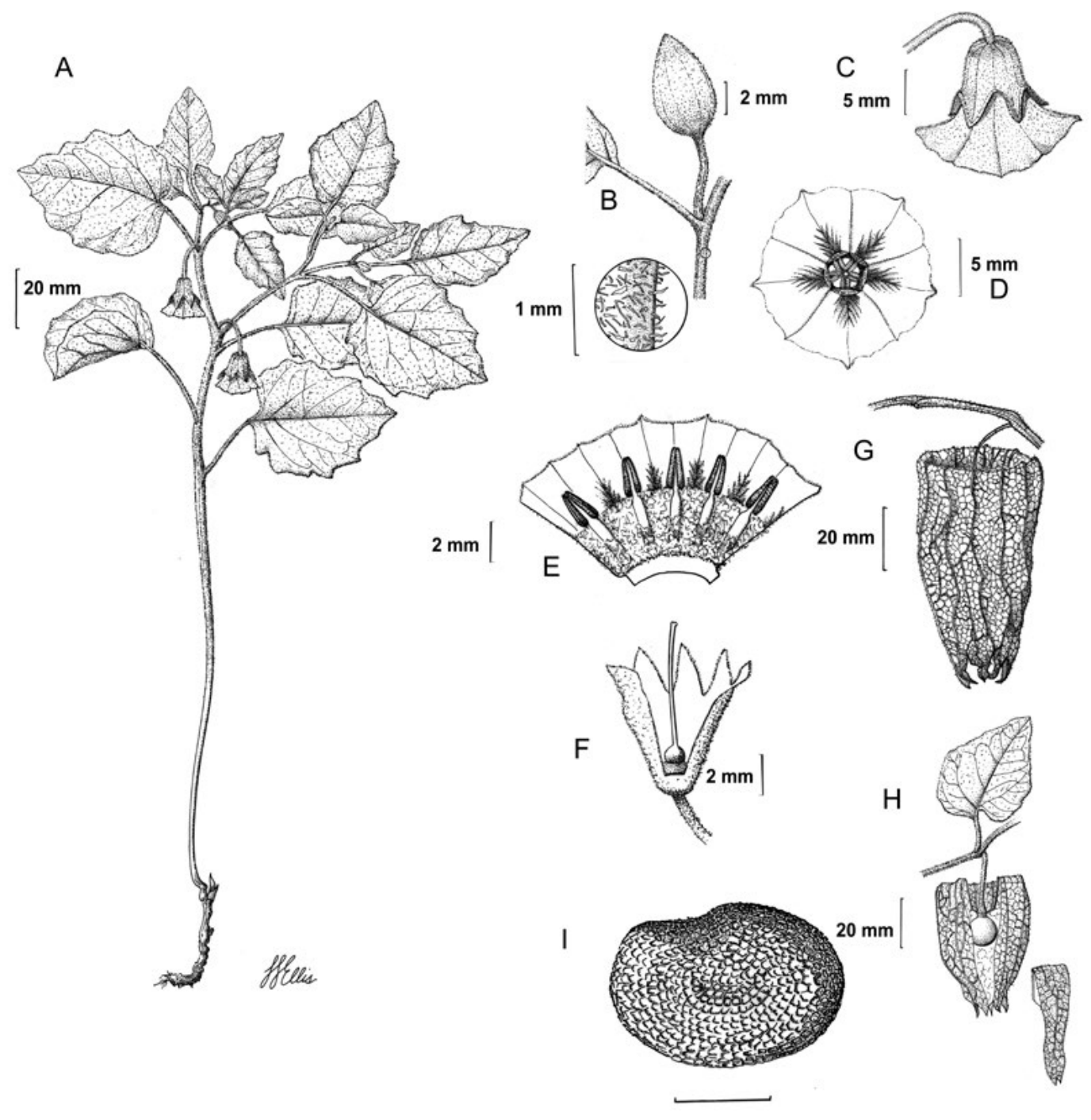

FIG. 7. Line drawings of Physalis macrosperma by Linda Ellis. A. whole plant. B. bud and close-up of stem hairs. C. lateral view of flower. D. distal view of corolla. E. interior of corolla showing stamens. F. calyx at anthesis, cut to show pistil. G. mature inflated calyx. H. calyx cut to show suspended berry. I. seed.

Correll and Johnston (1970). These are roughly equivalent to the "East Central Texas Plains" and "South Central Plains" of U.S. EPA (2013). Physalis macrosperma is restricted to these two ecoregions and it exhibits phytogeographic pattern 14 of Sorrie and Weakley (2001). The WGCP is part of the North American coastal plain biodiversity hotspot (Noss et al. 2015; Noss 2016); the WGCP sand formations harbor a rich endemic psammophytic flora (plants of sandy soils) and are well-known for their distinctive vegetation (MacBryde 1933; Gould 1962, 1969; MacRoberts et al. 2002a; MacRoberts et al. 2002b; Singhurst et al. 2003).

The Post Oak Savannah Ecoregion (POER) covers about 30,000 sq. km of undulating to hilly terrain 90-250 m in altitude, on droughty entisols (MacBryde 1933; Gould 1962, 1969; MacRoberts et al. 2002a; Singhurst et al. 2003). Much of this ecoregion is covered by a deep arenaceous mantle of the Sparta, Queen City, and Carrizo formations. These siliceous formations extend as narrow bands from southern Texas, with its subarid climate, generally trending northeast 720 kilometers (McBryde 1933; Sorrie \& Weakley 2001) to a more 


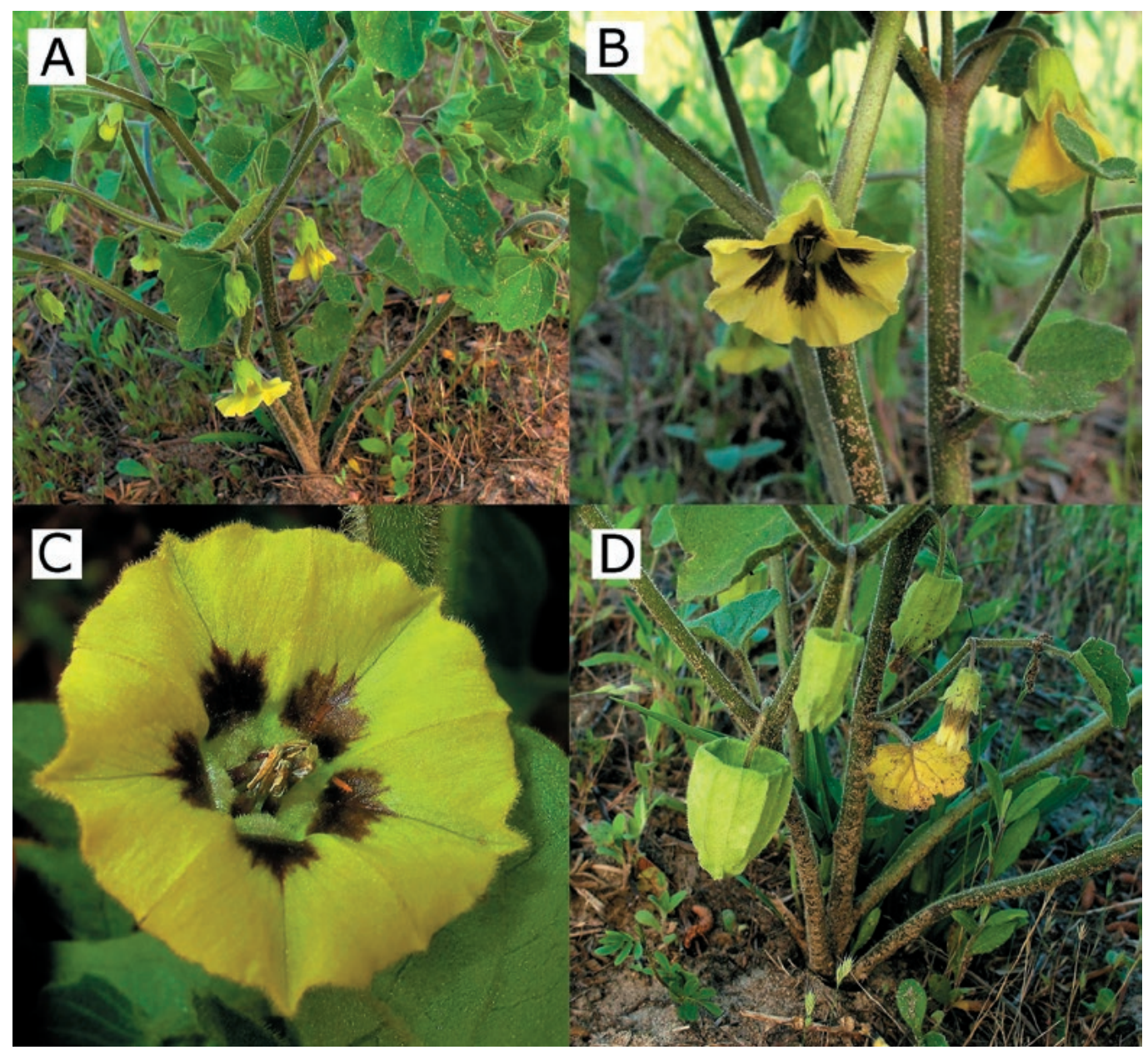

FIG. 8. Physalis macrosperma. A. flowering plants in situ. B. flowers on plants in situ. C. flower close-up. D. fruiting plants in situ. All photos taken by Craig Fraiser at Miller County Sandhills Natural Area in Arkansas, April/May 2014.

humid climate with hot summers and mild winters. Within the POER the new entity is most frequently encountered on the deep sands within south-central and east-central Texas. Sorrie and Weakley (2001) list ten endemic taxa from these deep sands: Abronia macrocarpa L. A. Galloway, Brazoria pulcherrima Lundell, Chaetopappa imberbis (A. Gray) G.L. Nesom, Coreopsis nuecensis Heller, Crataegus nananixonii Phipps \& O'Kennon, Hymenopappus carrizoanus B. L. Turner, Monarda viridissima Correll, Palafoxia hookeriana Torr. \& A. Gray. var. minor Shinners, Paronychia setacea Torr. \& A. Gray, Polygonella parksii Cory, Rhododon ciliatus (Benth.) Epling., and Thelesperma flavodiscum (Shinners) B.L. Turner. The environments on these deep sand formations may be referred to as "xeric sand barrens" (NatureServe 2018).

Physalis macrosperma is principally associated with the deeper deposits of Sparta, Queen City, and Carrizo sands. It is found on the somewhat excessively drained fine sandy entisols (Arenosa soil series -Typic Quartzipsamments),on fine loamy sandy alfisols (Grossarenic Paleustalfs), and, less frequently, on related siliceous soil subgroups (Psammentic Paleudalfs, Grossarenic Paleudults, and Arenic Paleudults). The quartzipsamments and sandy alfisols have over a meter of sandy upper epipedon with a subsoil of sandy loam or a sandy clay loam argillic horizon present in the alfic-sands (Paleustalfs). P. macrosperma inhabits xeric sandhill 
woodlands, sand savannas, or open sand barrens with a widely scattered open-canopy of gnarled oaks (Quercus incana W. Bartram, Q. marilandica Münchh., Q. margarettae [Ashe] Small. Many of the Carrizo sand psammophytes also historically occurred on Eocene sands in the POER of Texas (Correll \& Johnston 1970), more so than they are now in one or more of these "extension" regions, even though most have scattered, relatively isolated, and disjunct locations east of the POER within the Pineywoods Ecoregion.

Physalis macrosperma occurs as scattered populations within the Pineywoods Ecoregion (PWER) of eastern Texas, southwestern Arkansas, and western Louisiana on xeric sandhills embedded in pinelands with a scattered canopy of xeric oaks, pines (Pinus taeda L., Pinus palustris Mill.). Sandhill habitats of Physalis macrosperma within high pinelands dominated by longleaf pine (P. palustris) are confined to southeastern Texas and southwest Louisiana. Within the PWER, Physalis macrosperma is recorded from Cass, Nacogdoches, Polk, and San Augustine counties of Texas, as well as several parishes in Louisiana, and Miller County, Arkansas. These are often geographically isolated deep sands embedded in upland pinelands that are otherwise surrounded by square kilometers of unsuitable soils.

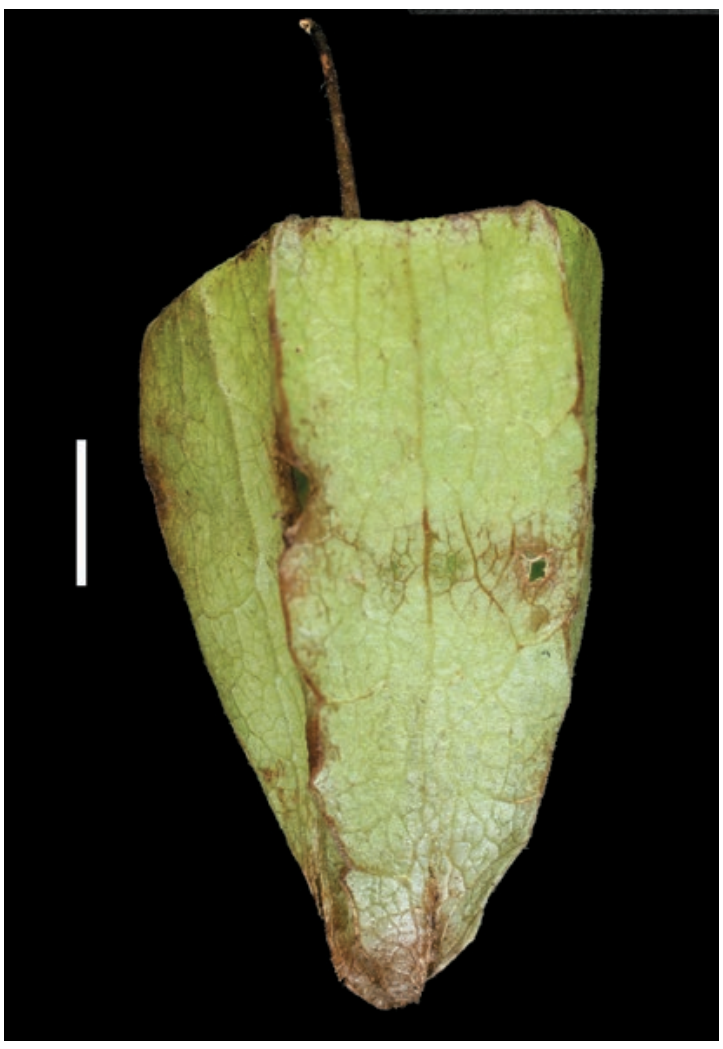

FIG. 9. Physalis macrosperma; fresh mature fruiting calyx; scale bar $=10 \mathrm{~mm}$. Photo by Milo Pyne, taken 13 June 2014 at Herbarium NCU of material collected by Craig Fraiser at Miller County Sandhills Natural Area in Arkansas (topotype).

This situation is somewhat similar to the difference between the "fall line sandhill region" of the Atlantic Coastal Plain in the Carolinas and Georgia, where xeric sand specialists were once common, and that of the adjacent inner coastal plain, where sandhills are infrequent and geographically restricted. While the Atlantic Coastal plain sandhills are of Cretaceous age, the inner coastal plain is mostly Eocene age. But in contrast, there is not a significant geological difference in these different habitats on the Texas coastal plain. In Texas, the Cretaceous region is mostly Blackland Prairie on vertisol clays, the Eocene region consists of alternating bands of deep sands, shallow sands, and clays. These bands often thin eastward, with the deepest sands often being near their western escarpment. Some associates of P. macrosperma from the sandhills within the PWER of Caddo Parish, Louisiana (R. Dale Thomas, pers. comm. ca. 1990) include: Coreopsis intermedia Sherff, Cnidosculus texanus (Muell. Arg.) Small, Crataegus uniflora Münchh., Froelichia floridana (Nutt.) Moq., Hymenopappus artemisiaefolius DC., Matelea cynanchoides (Engelm.) Woods., Mirabilis albida (Walter) Heimert., Penstemon murrayanus Hook., Phacelia hirsuta Nutt., Polygonella americana (Fisch. \& C.A. Mey.) Small, Stylisma pickeringii (Torr. ex Curtis) A. Gray var. pattersonii (Fern. \& Schub.) Myint., Thelesperma filifolium (Hook.) A. Gray, Viburnum rufidulum Raf., and Vitis lincecumii Buckl.

The micro-habitats for Physalis macrosperma and Cyperus grayioides Mohlenbrock are similar, both inhabiting xeric sand barrens, which are rather unstable aeolian sand dunes (Bridges \& Orzell 1989). Both are xeric sand specialists found on Eocene sands and sporadically but rarely on Pleistocene-aged stream terrace sand ridges below these formations, as well as on the Willis (Quaternary) and Catahoula (Miocene) Formations 


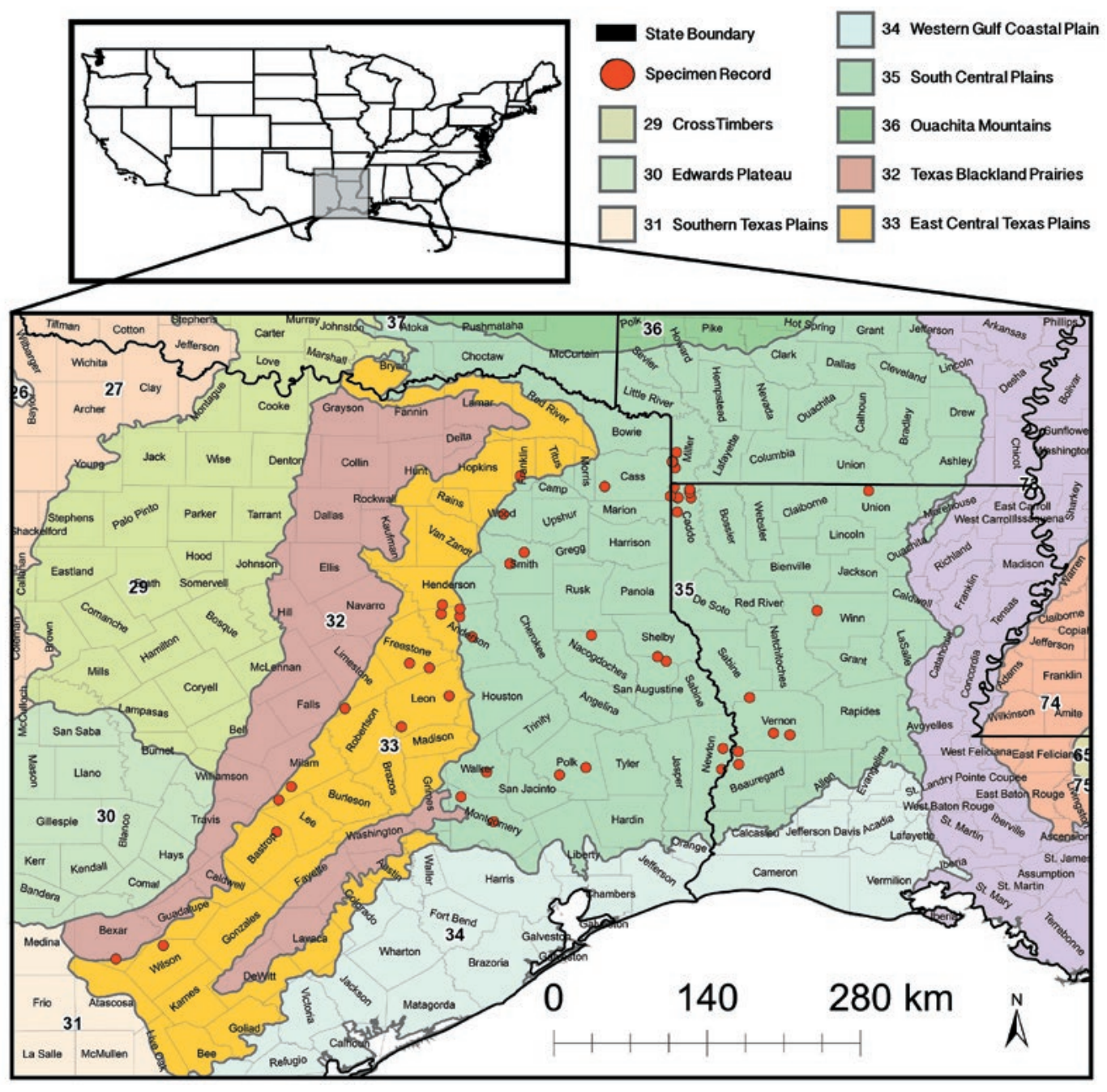

FIG. 10. Distribution of Physalis macrosperma based upon herbarium specimens within the West Gulf Coastal Plain of Texas, Louisiana, and Arkansas. Both the Post Oak Savannah (POER) and Pineywoods (PWER) ecoregions of Gould (1962, 1969), as mapped in Correll and Johnston 1970, are roughly equivalent to the "East Central Texas Plains" and "South Central Plains" of US-EPA (2013), except for the lack of mapping of blackland prairie bands within the "East Central Texas Plains" on this map.

in extreme southeastern Texas. The sands which provide habitat for Physalis macrosperma in the coastal plains of Louisiana, Texas, and Miller County, Arkansas are apparently of Tertiary or younger age. Species which are frequently associated with Cyperus grayioides throughout most of its Texas range include Aristida desmantha Trin. \& Rupr., Bulbostylis ciliatifolia (Elliott) Fernald, Cassia fasciculata Michx., Cnidoscolus texanus, Croton argyranthemus Michx., Crotonopsis linearis Willd., Dichanthelium ovale (Elliott.) Gould \& Clark subsp. villosissimum (Nash) Freck. \& Lelong, Diodia teres Walter, Eriogonum multiflorum Benth., Euphorbia cordifolia Ell., Froelichia floridana (Nutt.) Moq., Croptilon divaricatum (Nutt.) Raf., Helianthemum georgianum Chapm., Helianthus debilis Nutt., Hymenopappus artemisiifolius DC., Ilex vomitoria Ait., Lechea mucronata Raf., Matelea cynanchoides, Monarda punctata L., Opuntia macrorhiza Engelm., Paronychia drummondii Torr. \& A. Gray, Paspalum setaceum Michx., Polanisia erosa (Nutt.) Iltis, Polypremum procumbens L., Quercus incana, Quercus 
stellata Wang., Schizachyrium scoparium (Michx.) Nash, Scutellaria cardiophylla Engelm. \& A. Gray, Bryodesma arenicola (Underwood) Sojak ssp. riddellii (Van Eseltine) Skoda, Stillingia sylvatica L., Stylisma pickeringii A. Gray, Tephrosia virginiana (L.) Pers., Thelesperma filifolium, Tradescantia reverchonii Bush, Triplasis purpurea (Walter) Chapm., and Vaccinium arboreum Marshall (Bridges \& Orzell 1989). These species would also be expected to occur at sites with Physalis macrosperma.

Physalis macrosperma occurs in pyrogenic-evolved savanna-woodlands where fire maintains the openpark-canopy of sandhill vegetation and prevents sand barren gaps from becoming overgrown with fire-suppressed woody species. The sandhills within the Post Oak Ecoregion are thought to have historically been maintained by lightning-ignited wildfires and grazing bison (Stambaugh et al. 2014). Within the Pineywoods Ecoregion, Physalis macrosperma occurs in sandhills embedded within pyrogenic pinelands with a scattered canopy of xeric oaks and/or pines (Pinus taeda, Pinus palustris). Physalis macrosperma localities within the longleaf dominated pinelands are the most fire-frequented of its habitats and have been shown to have been historically maintained by a biennial ignited fire regime (Stambaugh et al. 2011). Despite the importance of burning, the role of fire in the life history of Physalis macrosperma remains unstudied. Its post-fire adaptive strategy (re-seeder or re-sprouter syndrome) has yet to be determined and its flowering response post-burning has not been assessed. 


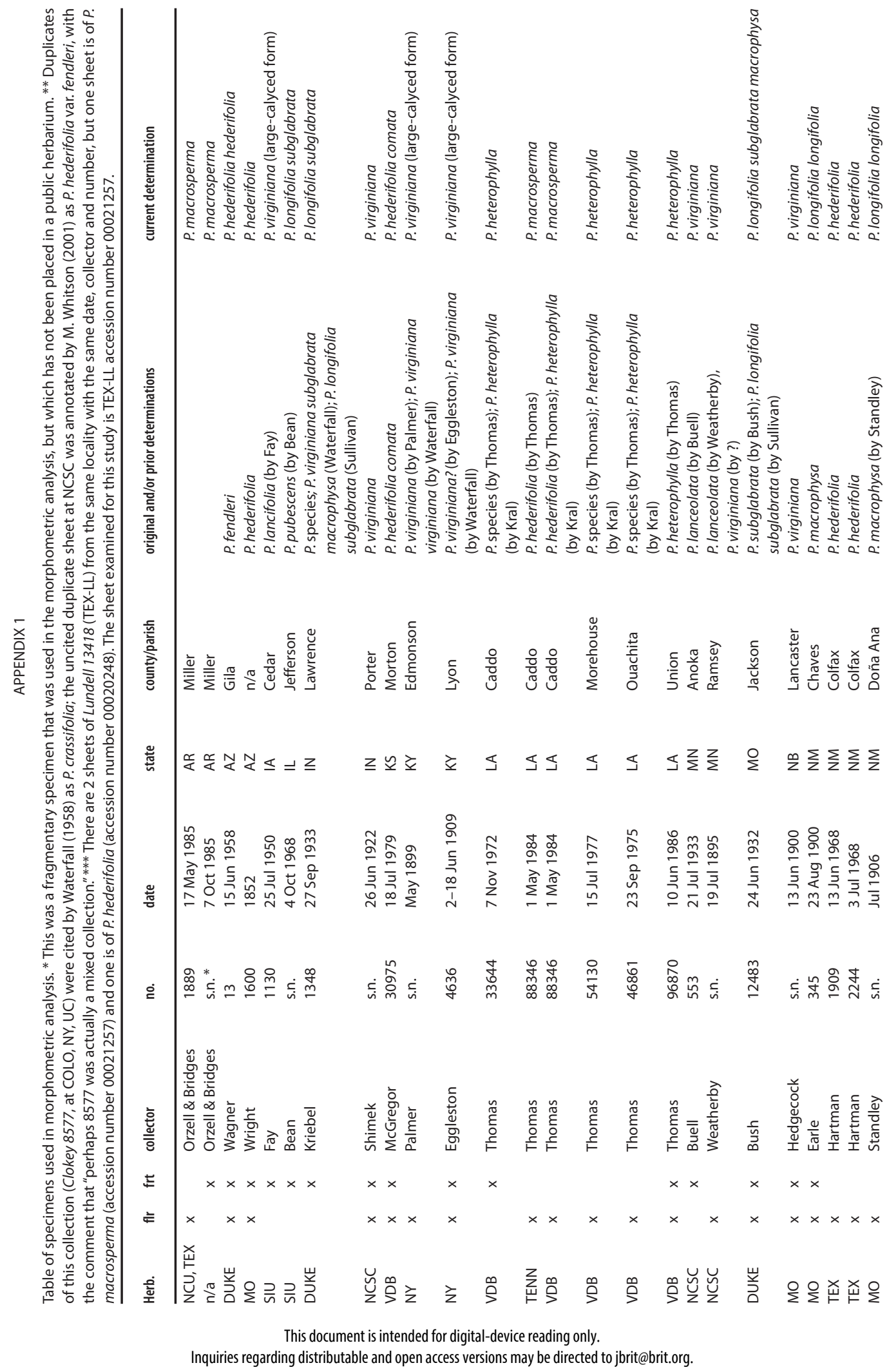




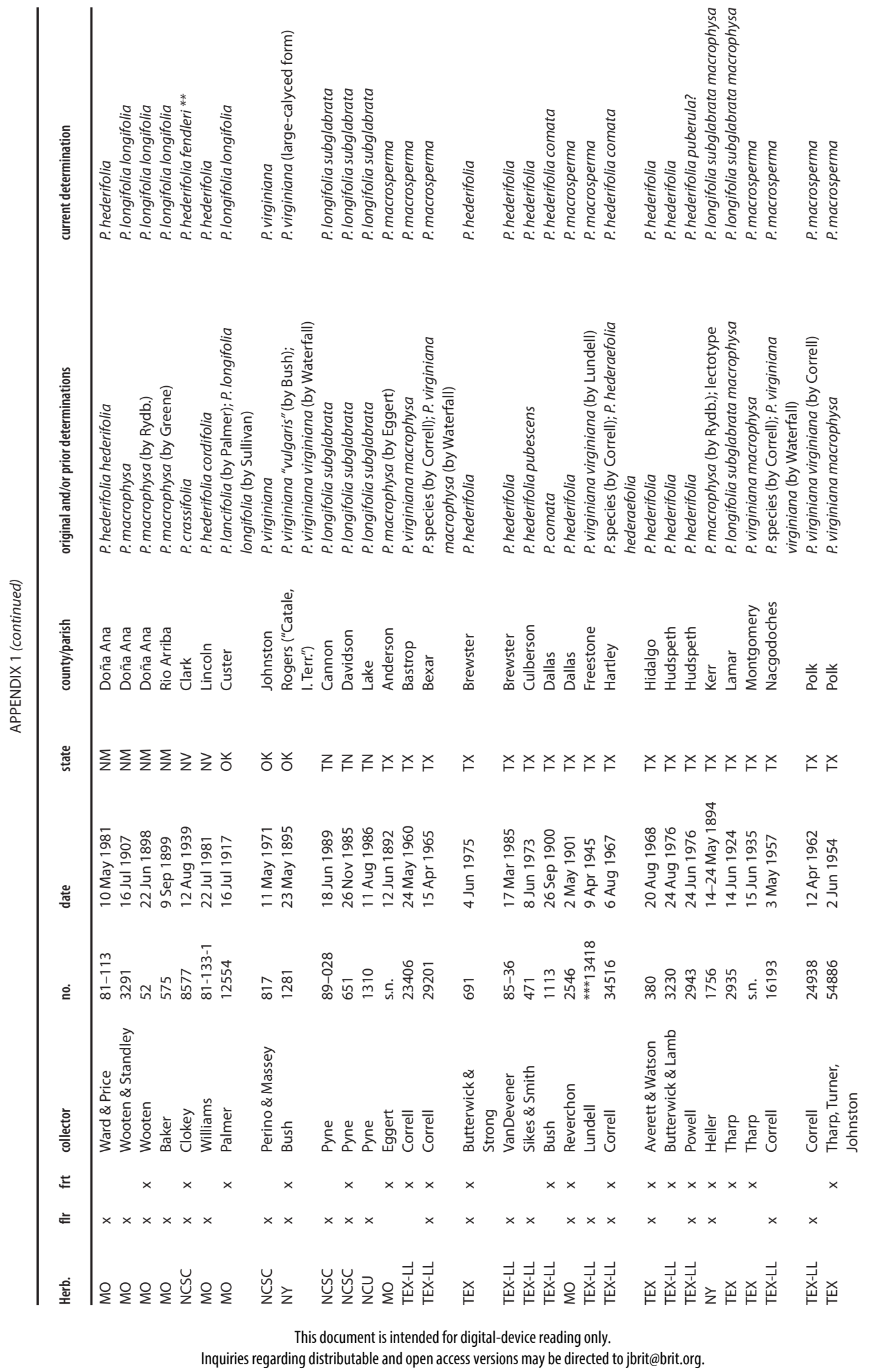




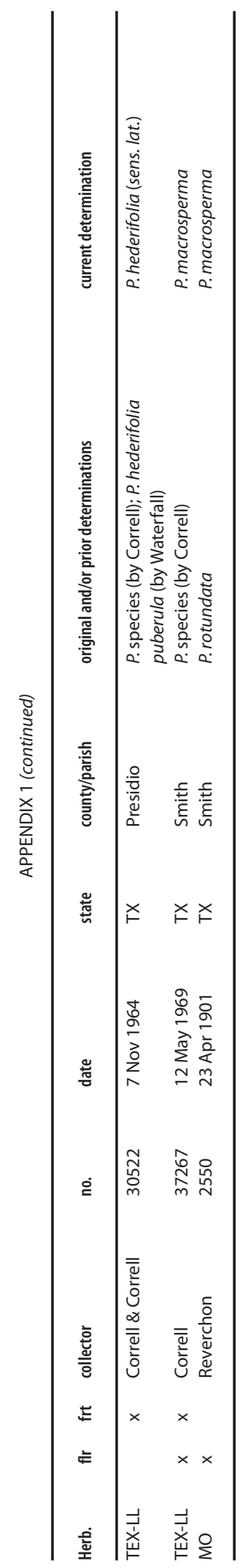




\section{APPENDIX 2}

Catalogue of known specimens of Physalis macrosperma. Asterisks $\left(^{*}\right)$ denote the specimens measured for morphometric analysis.

Physalis macrosperma. U.S.A. ARKANSAS. Miller Co.: sandhills W side of AR 237 ca. 0.7 mi S of AR 134 ca. 0.5 mi E of TX state line, 17 May 1985, Orzell \& Bridges 1889 (NCU*, TEX); same locality, 12 Aug 1985, Orzell \& Bridges $2693 a$ (NCU); W of AR 237 and N of Macedonia Baptist Church, 24 May 1993, Thomas 134241 (BRIT, NLU, USCH); cemetery and roadside of AR 237 at Macedonia Baptist Church 1 mi N of U.S. 71 in Mount Pleasant Community S of Texarkana, 24 May 1993, Thomas 134291 (NLU); W of AR 237 and E of Nature Conservancy Preserve $4.8 \mathrm{mi}$ N of AR 160 SW of Sulphur River Wildlife Management Area, 16 Aug 1996, Thomas 151294 (NLU); Sandy soil in and around the cemetery of Macedonia Baptist Church beside AR 237 ca. 1 mi N of AR 160 W of Doddridge, 27 May 1999, Thomas 160834 (NLU); same locality, 27 May 1999, Thomas 160835 (NLU); Sand Hills State Natural Area W of AR 237, 7 Jun 2000, Gentry 9238 (ANHC, BRIT [holotype], LSU, NCU, NY, US); same locality, 8 Jun 2000, Gentry 9174, (ANHC); Miller County Sandhills Natural Area xeric sandhill barrens, 8 Jul 2005, Witsell 05-0717 (ANHC). LOUISIANA. Beauregard Parish: Merryville North Savannah ca. 3 mi E and 1.2 mi N of Merryville, 11 Jun 1988 , Orzell \& Bridges 7250 (TEX); Caddo Parish: sandy woods with oaks and hickories, at Rogers Station, Sect. 23, ca. 5 mi S of Vivian, 15 Jun 1969, Thieret 31208 (LAF); decid. (?) woods E of Raspberry Rd., NW 1⁄4 SE 1/4 S24 T16N R15W, 31 Mar 1971, D. MacRoberts 128 (LSUS); dry, sandy hilltop in oak-pine woods beside U.S. 71, 2.5 mi S of Mira, 22 May 1975, Thomas 43964 (NLU); dry sandy hills 0.5 mi N of Mira, 31 Aug 1976, MacRoberts 1942 (LSU); very dry sandy soil on E side of U.S. 71, 2 mi S of Ida and N of Mira, 7 May 1982, Thomas 80845 (NLU); along Kendrick Road west of LA 1, 2.7 mi N of Vivian, 1 May 1984, Thomas 88346 (BRIT, CM, DUKE, FLAS, LSU, NCU, NLU, TENN*, USF, VDB); same locality, 15 May 1984, Thomas 88704 / Taylor 6994 (NLU, USF); same locality, 1 Jun 1984, Thomas 89017 / Taylor 7189, (BRIT, NLU, USCH); sandy hill W of U.S. 713 mi S of Ida, 10 Jun 1985, Thomas 92393 (NLU); same locality, 10 Jun 1985, Thomas 92399 (USF); very sandy soil in clear-cut woods on hill W of U.S. 71 N of Mira and S of Ida, 1 Jul 1994, Thomas 140277 (NLU); Caddo Black Bayou TNC Preserve W of LA 1, ca 2 air mi NW of Rodessa, 31 May 2006, Reid 5785 (LSU). Sabine Parish: very dry longleaf pine woods beside LA 473 at Hornbeck Fire Tower W of Hornbeck, 7 Jun 1980, Thomas 71612 (NLU). Union Parish: frequent in disturbed area in pine forest along Union Parish Rd. 6670 ca 1.7 mi E of Laran, 3 Jun 1979, Allen 8843 / Vincent 2107 (LAF). Vernon Parish: pitcher plant bog. 1.75 mi SW of jct. Lookout Road and Whiskey Chitto Road, 17 May 1983, Givens 3020 (LSU); infrequent in pine forest off LA 392 ca 12.2 mi W of Annacocco (sic), 1 Jun 1983, Allen 12802 (LAF); roadbank and cleared area beside LA 464 at LA 111 S of Aldamane and N of Merryville, Lutcher and Moore Wildlife Management Area, 4 Jun 1986, Thomas 96527 (NLU); sandy longleaf pine forest on Fort Polk ca. 3.5 mi ESE of Pickering, 23 May 1991, Allen 17228 (NLU). Winn Parish: clear-cut hillside beside LA 1233 just N of LA 156 and E of Goldonna, 18 Oct 1981, Thomas 79121 (NLU). TEXAS. Anderson Co.: sandy ground N Palestine, 12 Jun 1892, Eggert s.n. (MO*); S side of Co Rd opp. intersection FR 860 ca. 1.3 mi E of TX 19 at Bois D'Arc, 4 May 1988, Orzell \& Bridges 6546 (BRIT, TEX); W of Wolf Creek, ca. 0.8 mi S of Union Church and 2.5 mi NW of int. FR 837, 4 May 1988, Orzell \& Bridges 6574 (NY, TEX); Engeling Wildlife Management Area, 8 Jun 1988, Orzell \& Bridges 7197 (TEX); openings in post oak - blue jack oak community on deep xeric sands, northern section of Engeling Wildlife Mgmt. Area, 12 May 2000, MacRoberts \& MacRoberts 4373 (TEX); same locality, 28 Jun 2000, MacRoberts \& MacRoberts 4560 (TEX). Bastrop Co.: in sandy oak woods (rolling) along route \#290 between McDade and Paige, 24 May 1960, Correll 23406 (TEX-LL*). Bexar Co.: Rt. 281, ca. 12 mi S of San Antonio, 15 Apr 1965 , Correll 29201 (TEX-LL*). Cass Co.: loose sands of post oak sand hills 10 m S of Bivins, 19 May 1984, Kral 71508 (VDB); roadside park on N side of TX 11, just W of Co Rd 2998, 19 Aug 1988, Orzell \& Bridges 8122 (BRIT, TEX); dry, sandy soil in clear-cut woods on hill beside county road 4452 S of FM 125 SE of McLeod, TX, along north-south road near the Louisiana State line, 24 May 2000, Thomas 165862 (DUKE, NLU). Dallas Co.: common in fields, 2 May 1901, Reverchon 2546 (MO*). Falls Co.: ca. 0.2 mi SE of TX 14 at a point ca. 3 mi N of Robertson Co. line, ca. 4.5 mi NE of Bremond, 7 Jun 1989, Orzell \& Bridges 10464 (TEX). Franklin Co.: S side of FR 900, ca. 1.3 mi W of FM 115, 6.2 mi S of I-30 on S side of Mount Vernon, 19 Aug 1988, Orzell \& Bridges 8118 (TEX). Freestone Co.: off US 75 SE of Dew, 9 Apr 1945, Lundell 13418 [there are two sheets at TEX-LL with this collector, number and date; this one is accession number 00021257; the other sheet (accession number 00020248) represents P. hederifolia Gray (fide Waterfall)] (TEX-LL*); $0.2 \mathrm{mi}$ SW of Tinsley Rd at Mustang Creek $6.7 \mathrm{mi}$ NE of intersection US 75 at Buffalo, 6 May 1988, Orzell \& Bridges 6623 (TEX). Henderson Co.: 2 mi NE of Athens, sandy roadside, flowers pale brownish ochre, fruiting calyx deeply indented at pedicel end, 8 May 1948, Shinners 10047 (SMU); S of Coon Creek Lake, ca 0.2 mi S of Wilson Lake dam, 4 May 1988, Orzell \& Bridges 6567 (BRIT, NY, TEX). Leon Co.: 0.2 mi W of Cherokee Lake 0.1 mi N of main road through Hilltop Lakes Resort, 2 May 1988, Orzell \& Bridges 6486 (TEX); same location, 7 Jun 1988, Orzell \& Bridges 7163 (BRIT, TEX); same location, 5 Jun 1989 , Orzell \& Bridges 10298 a (BRIT, GH, MO, NY, TEX); same location, 6 Jun 1989, Orzell \& Bridges 10329 (BRIT, MO, TEX); NE corner of intersection of TX 7 and FM 1511 at Hopewell, 3 May 1988, Orzell \& Bridges 6498 (BRIT, MO, TEX). Madison Co.: roadbank, deep Padina sand, dry, part shade, calyx green, herb with Pinus taeda, Quercus falcata, USGS Elwood quadrant, NW quarter, 13 May 1998, McNeill 1724 (BRIT). Milam Co.: FM 1786 ca. 6 mi SW of Rockdale, 7 Jun 1989, Orzell \& Bridges 10451 (BRIT, TEX). Montgomery Co.: Conroe, 15 Jun 1935 , Tharp s.n. (TEX*); 7.3 mi S of Richards on FM 149 Sam Houston National Park, 26 Jun 1973, Saichuk 77 (LSU). Nacgodoches Co.: ca. 8 mi S of Mt. Enterprise, in pine-hardwood forest, 3 May 1957, Correll 16193 (TEX-LL*). Newton Co.: off TX 1414 ca 7 mi SE of Burkeville, 17 Jul 2010 , Allen 22085 (LSU); same location, 16 Jul 2011, Allen 22343 (LSU). Polk Co.: 2.2 mi N of US 190 on road from the Indian reservation to Camden, 2 Jun 1954, Tharp 54886 (TEX*); S edge of Livingston, 12 Apr 1962, Correll 24938 (TEX-LL*). San Augustine Co.: TX 147, from 0-0.4 mi S of jct. FM 1279 ca. 5 mi N of San Augustine, 27 Oct 1989, Orzell \& Bridges 12751 (TEX). Shelby Co.: very sandy soil E of U.S. 96 at FM 417, 12 mi S of Center, cleared area under electrical transmission lines, 29 May 1992, Thomas 129192 (NLU). Smith Co.: Lindale, sandy woods, common in sand, 23 Apr 1901, Reverchon 2550 (MO*); sands, Swan, Texas, 9 May 1902, Reverchon 3236 (SMU); Tyler State Park, 10 mi N of Tyler, sandy hillside, in sun, locally rather common, flowers light ochre-yellow with brown center 16 May 1948 , Shinners 10116 (SMU); N edge of Tyler the intersection) of Loop 323 and Rte 69, 12 May 1969, Correll 37267 (TEX-LL*); beside road to Harris Creek Church N of I-20 at FM 2015 S of Winona, Texas, dry area with cactus and cedar, 10 Sep 1971, Thomas 25064 (NLU). Van Zandt Co.: Co Rd 29085.7 mi from jct. 19 \& 1861, 6 Jun 1993, Lehto L25771 (BRIT). Walker Co.: sandy open ground, Huntsville, 24 May 1917, Palmer 12022 (TEX). Williamson Co.: Co Rd 0.7 mi N of intersection FM 112 ca. 1.5 mi E of intersection FM 486 at Shiloh, 12 Jun 1989, Orzell \& Bridges 10582 (BRIT, GH, MO, NY, TEX). Wilson Co.: SE edge of Post Oak Road, 0.2 mi SW of jct. with US Rt. 87, 22 Jun 1999, Pyne 99-005 (BRIT, LSU, NCU, TEX, ANHC). Wood Co.: 0.1 mi N of Co Rd 3245 ca. 5 air mi SE of Quitman, 18 Aug 1988, Orzell \& Bridges 8065 (BRIT, TEX). 


\section{ACKNOWLEDGMENTS}

Thanks are due to curators of BRIT, CM, DUKE, GH, LAF, LSU, MO, NCSC, NCU, NLU, NY, SIU, SMU, TEX, TEX-LL, UC, US, USCH, USF, and VDB for loans of specimens, provision of digital images, and access to specimens during our visits to various herbaria. Thanks to Christopher Reid, Chris Doffit, and Keith Cascio (retired) of the Louisiana Department of Wildlife and Fisheries; Carol Ann McCormick and Shanna Oberreiter (NCU) for assistance with handling loans of specimens and imaging; Craig Fraiser for permission to use his digital photographs of living plants in situ and Linda Ellis for her excellent illustrations. The manuscript was greatly improved by critical review comments and input from Rocío Deanna, Mahinda Martínez Díaz, Barney Lipscomb, and an anonymous reviewer. We are also grateful to Janet Sullivan, Rocio Deanna, and Mary Kathryn (Maggie) Whitson for their guidance and technical support during manuscript preparation. Special thanks to Bill Carr of the Texas Department of Parks and Wildlife who assisted with field work. We are also grateful for financial support to defray publication costs from the Arkansas Natural Heritage Commission and assistance from the Edward C. Swab Fund for Floristic Botany of the Herbarium of the University of North Carolina at Chapel Hill.

\section{REFERENCES}

APPLEQUIST, W.L. 2012. Report of the Nomenclature Committee for Vascular Plants: 64. Taxon 61(5): 1108-1117. (To conserve Physalis L. (Solanaceae) with conserved type; p. 1112).

BRIDGES, E.L. \& S.L. OrzelL. 1989. Additions and noteworthy vascular plant collections from Texas and Louisiana, with historical, ecological and geographic notes. Phytologia 66(1):12-69.

CASCIO, D.K. 1994. Solanaceae of Louisiana. Master of Science Thesis, Northeast Louisiana University, Monroe, U.S.A.

CoRRELL, D.S. \& M.C. JoHnston. 1970. Manual of the vascular plants of Texas. Texas Research Foundation, Renner, Texas, U.S.A.

CRONQUIST, A. 1980. Vascular flora of the southeastern United States, Volume 1, Asteraceae. University of North Carolina Press, Chapel Hill, North Carolina, U.S.A.

GouLD, F.W. 1962. Texas plants - a checklist and ecological summary. MP-585. Texas Agri. Exp. Sta., College Station, Texas, U.S.A.

GouLD, F.W. 1969. Texas plants - a checklist and ecological summary. MP-585/Revised. Texas Agri. Exp. Sta., College Station, Texas, U.S.A.

MacRoberts, B.R., M.H. MacRoberTs, \& J.C. CAthey. 2002a. Floristics of xeric sandylands in the Post Oak Savanna region of east Texas. Sida 20(1):373-386.

MacRoberts, M.H., B.R. MacRoberTs, B.A. SorRIE, \& R.E. Evans. 2002b. Endemism in the West Gulf Coastal Plain: Importance of xeric habitats. Sida 20(2):767-780.

MARTINEZ, M. 1999. Infrageneric taxonomy of Physalis. In: M. Nee, D.E. Syman, R.N. Lexter, \& J.P. Jessops, eds. Solanaceae IV: Advances in biology and utilization. Royal Botanic Gardens, Kew, U.K. Pp. 275-283.

McBRYDE, J.B. 1933. The vegetation and habitat factors of the Carrizo sands. Ecol. Monogr. 3:249-297.

Noss, R.F., W.J. Platt, B.A. Sorrie, A.S. Weakley, D.B. Means, J. Costanza, \& R.K. Peet. 2015. How global biodiversity hotspots may go unrecognized: lessons from the North American Coastal Plain. Diversity \& Distrib. 21: 236-244.

Noss, R.F. 2016. Announcing the World's $36^{\text {th }}$ Biodiversity Hotspot: The North American Coastal Plain. https://www.cepf. net/stories/announcing-worlds-36th-biodiversity-hotspot-north-american-coastal-plain.

PYNE, M. 2018. The status of Physalis hederifolia (Solanaceae) in Louisiana, U.S.A. J. Bot. Res. Inst. Texas 12(1):317-321.

Pyne, M., S. OrzelL, \& E.L. Bridges. 2019. Physalis macrophysa (Solanaceae: Physalinae: subgenus Rydbergis) its taxonomic disposition and relation to other material with large inflated fruiting calyces. J. Bot. Res. Inst. Texas 13:51-61.

RydBerg, P.A. 1896. The North American species of Physalis and related genera. Mem. Torrey Bot. Club 4(5):297-374.

Singhurst, J.R., J.C. CATHY, D. Prochaska, H. HaUCKE, G.C. KRoH, \& W.C. Holmes. 2003. The vascular flora of Gus Engeling Wildlife Management Area, Anderson County, Texas. S. E. Naturalist (Steuben) 2:347-368.

SoRRIE, B.A. \& A.S. WEAKLEY. 2001. Coastal plain vascular plant endemics: Phytogeographic patterns. Castanea 66:50-82.

Stambaugh, M.C., R. Guyette, \& J.M. Marschall. 2011. Longleaf pine (Pinus palustris Mill.) fire scars reveal new details of a frequent fire regime. J. Veg. Sci. 22:1094-1104.

Stambaugh, M.C., J.C. Sparks, \& E.R. Abadir. 2014. Historical pyrogeography of Texas, USA. Fire Ecol. 10(3):72-89. 
Sullivan, J.R. 2004. The genus Physalis (Solanaceae) in the southeastern United States. Rhodora 106(928):305-326.

SULLIVAN, J.R. 2013. Nomenclatural innovations in North American Physalis (Solanaceae). Rhodora 115(963):290-292.

Sultivan, J.R. [in press]. Physalis (Solanaceae). In: Flora of North America north of Mexico, Vol. 14. Oxford Univ. Press, New York, U.S.A., and Oxford, U.K.

THomAs, R.D. ca. 1990. Personal Communication.

U.S. Environmental Protection Agency (EPA). 2013. Level III Ecoregions of the continental United States. U.S. EPA, National Health and Environmental Effects Research Laboratory, Corvallis, Oregon, U.S.A. Map scale 1:750,000. [ftp://ftp.epa. gov/wed/ecoregions/us/Eco_Level_III_US.pdf]

Vargas, O., M. Martinez, \& P. Davila. 2001. Two new species of Physalis (Solanaceae) endemic to Jalisco, Mexico. Brittonia 53:505-510.

WANG, R. 2014. A new combination in Alkekengi (Solanaceae) for the Flora of China. Phytotaxa 178(1):59-60. https:// biotaxa.org/Phytotaxa/article/view/phytotaxa.178.1.9/9838

Waterfall, U.T. 1958. A taxonomic study of the genus Physalis in North America north of Mexico. Rhodora 60:107-114, $128-142,152-173$.

Waterfall, U.T. 1967. Physalis in Mexico, Central America, and the West Indies. Rhodora 69:82-120, 203-239, 319-329.

Whitson, M. \& P.S. MAnos. 2005. Untangling Physalis (Solanaceae) from the physaloids: A two-gene phylogeny of the Physalinae. Syst. Bot. 30(1):216-230.

Wilf, P., M.R. Carvalho, M.A. Gandolfo, \& N.R. Cuneo. 2017. Eocene lantern fruits from Gondwanan Patagonia and the early origins of Solanaceae. Science 355:71-75.

Zamora-Tavares, M. del P., M. Martinez, S. Magallon, L. Guzman-Davalos, \& O. Vargas-Ponce. 2016. Physalis and physaloids: A recent and complex evolutionary history. Molec. Phylogen. Evol. 100:41-50. 